\title{
Preface: The Genesis of this Book
}

What do you do with an idea? Do you walk away from it or do you nourish it? Do you show it to others or do you hide it? In a pre-school story book ${ }^{1}$ about an 'idea', these are the questions four-year-olds learn to answer. Pre-schoolers learn that they can 'change the world', with an idea.

The inception of the present book also started with an idea in 2011, when Bahar read and reviewed a tribute volume honoring the work of another scholar. ${ }^{2}$ The idea was to develop a similar tribute in honor of Ofelia García - a leading sociolinguist, educational linguist and educator of our time, who tremendously inspired both of us while we both had the privilege of working with her as our doctoral advisor and academic mentor during our memorable years of doctoral studies (2005-2009) at Columbia University's Teachers College. In 2012, when we first discussed the idea of developing a tribute volume in honor of our beloved Ofelia, we were both excited at such a possibility.

We thought of ourselves as a good match, for we had worked with Ofelia on different lines of interest concerning language studies. Bahar's research was on discourse analysis, bilingual education and bilingual community education, whereas Maryam's research concerned the sociological, economic and political aspects of language in schools and societies. At the time, Bahar had just co-edited (with Ofelia García and Zeena Zakharia) a book on the theme of 'Bilingual Community Education and Multilingualism', ${ }^{3}$ whereas Maryam's book on the theme of the 'Politics of Educational Borrowing and Lending' ${ }^{4}$ was already in press. In spite of our different research focuses, our common transnational perspective made us eager to construct a global lens to guide us in our academic, professional and personal lives. None of these would have been possible had we not had the privilege of working with Ofelia.

A tribute volume for a renowned and accomplished scholar like Ofelia García sounded just right to both of us. 'It would be a meaningful gift, a personal homage and a way of showing our appreciation for 
her', were the words we said to one another in 2012. Regardless of our immense passion for such collaboration, we could not do it at the time, for we were both busy with new positions, unforeseen health issues and family-related matters. Bahar attempted to restart it a few years later with someone else, but again 'life happened' (a favorite phrase that we borrowed from Ofelia).

When we spoke about this project again in 2020, it was not only the right time but also a historic time for both of us. It was the right time, for throughout the ten years that had passed between conceptualizing the tribute volume idea and actually realizing it, Ofelia's proclivity to produce academic research continued to challenge then current zeitgeist in multilingualism. She had developed further her conceptualization of multilingualism, bilingual education and translanguaging, which led to her research within CUNY-NYSIEB (City University of New York-New York State Initiative on Emergent Bilinguals) and was well-received amongst the sociolinguistic community. It was equally a historic time, for the Covid-19 pandemic had taken hold, threatening the social order millions were infected, many died, strict social distancing guidelines and lockdowns led to economic uncertainty, job loss and financial anxiety, and still many others yearned for their pre-Covid-19 lifestyle. Within such a circumstance, what did not go away from our minds was the idea of this project; an idea that eventually took flight in August 2020.

Entitled Remaking Multilingualism: A Translanguaging Approach, this tribute volume is about the remaking of multilingualism; a collective movement initiated by Ofelia García and her close network of remarkable allies, prolific scholars and leading educators from throughout the world who have devoted their professional and academic lives to the cause of linguistic equality, justice, pluralism, diversity and inclusion in schools and societies worldwide. Using translanguaging as its underlying approach, this book takes the reader beyond named languages and named nation states to place the emphasis on us, human beings, the speakers of different languages and the residents of different parts of the world; it is about us and the ways through which we use all our resources (linguistic, meta-linguistic and socio-cultural) to live, work and communicate with one another in the backdrop of inequality in our highly stratified globalized world of the twenty first century.

This book can be considered a true international collection, which offers its readers a wide array of perspectives, languages, places and writing styles. Like the concept of 'translanguaging', the underlying approach of this book, the contributors of this volume are truly transnational, belonging to various localities of the world. They speak different languages as their first, second first, third or more languages. Regardless of their belonging to various speech communities or nation states, the contributors of this volume care about languages spoken by the people that surround them - their students, families, neighbors, 
co-workers and communities. Hence, through the pages of this book, we will travel to various localities or geopolitical spaces in the world to learn about the speakers of different languages (Chinese, English, French, Hebrew, Italian, Korean, Persian, Turkish and Spanish, among others), who are languaging or translanguaging here and there throughout the world.

We think that multilingualism should be placed at the heart of our global world because of the extents to which the positive and negative linguistic outcomes of globalization impact the lives of many people worldwide: the rich and the poor, the literate and illiterate, the linguistic majorities and minorities and the monolinguals and bi-/multilinguals of the world. Hence, it is our collective hope, both ours (the editors) and that of the contributors of this volume, that this book with its wide array of perspectives be of interest to people inside academia, including language scholars, professors and students. We equally hope this book will be of interest to those language teachers and practitioners, policy makers and transnational organizations who are involved directly or indirectly in language-related projects, and last but not least, to the citizens of the world, for whom multilingualism is a familiar term but yet vague concept in terms of its immense value for safeguarding the diversity of our planet.

Although this book bears our names as its editors, it is the outcome of a truly collective process, which came to life gradually but gracefully through interactions with many amazing individuals. We are flattered and honored to publish another book with Multilingual Matters. Our special thanks are due to Tommi Grover and Anna Roderick, Managing Director and Editorial Director of Multilingual Matters, respectively, for the excellent job they have been doing in raising awareness about multilingualism, linguistic pluralism and diversity by publishing such books. We would equally like to extend our appreciation to Professor $\mathrm{Li}$ Wei and Professor Angel M.Y. Lin, the editors of the Translanguaging in Theory and Practice series, who were very supportive of this project from the very beginning. This book would not have been possible without the chapter authors, to whom we are equally thankful.

In our academic institutions, Maryam would like to thank Rutgers, the State University of New Jersey, in general, and her Department of African, Middle Eastern, and South Asian Languages and Literatures, in particular, for their generous support in making it possible for her to work on this book project during her 2020-2021 Sabbatical Leave. Bahar would equally like to thank Mercy College and her Department of Literacy and Multilingual Studies for all their support. Last but not least, we both like to thank our families for their support, patience and understanding of us during our work on this book.

We would like to close this preface by commemorating our friends, colleagues and professors who were alongside us in our journey with 
Professor García, especially Professor María Torres-Guzmán, Dr Ruhma Choudhury and Dr Heesook Cheon, our beautiful friends and gifted individuals from Columbia University's Teachers College, whose untimely passing affected us all deeply.

\author{
Maryam Borjian, \\ Rutgers, The State University of New Jersey \\ Bahar Otcu-Grillman, \\ Mercy College, New York
}

\title{
Notes
}

(1) 'What do you do with an idea?' is the title of a children book by Yamada, K. and Besom, M. (2014). For the read-aloud of this book, please see: https://www.youtube. $\mathrm{com} /$ watch?v $=0$ We9 $\mathrm{zl} 5 \mathrm{~J} 7 \mathrm{hQ}$

(2) Hult, F.M. and King, K.A. (eds) (2011) Educational Linguistics in Practice: Applying the Local Globally and the Global Locally. Bristol: Multilingual Matters. This book was a tribute honoring the work of Nancy Hornberger (University of Pennsylvania), another leading scholar of our time, a close colleague and friend of Ofelia García's and a contributor to the present book. We are delighted to have her with us in this project.

(3) García, O., Zakharia, Z. and Otcu, B. (eds) (2013) Bilingual Community Education and Multilingualism: Beyond Heritage Languages in a Global City. Bristol: Multilingual Matters.

(4) Borjian, M. (2013) English Education in Post-Revolutionary Iran: From Indigenization to Internationalization. Bristol: Multilingual Matters. 